\title{
INTERNATIONAL CRIMINAL LAW AND THE SEPTEMBER 11 EVENTS
}

\section{Adel Safty*}

\begin{abstract}
The events of September 11 and the subsequent war against Afghanistan, which started less than a month later, raised important legal issues of international law. On the one hand, they raised the issue of criminal legal responsibility, the issues associated with legally apprehending and extraditing the offenders, and the issue of their public trial for crime against humanity. They also raised the issue of whether or not these events gave rise to a state of war. The war against Afghanistan raised the issue of whether or not a state, in this case the United States, could be at war with an entity less than that of a belligerent, the issue of self-defence, either by reference to customary international law or by reference to the United Nations Charter. It also raised the issue of individual and state criminal responsibility and the issue of extension of individual responsibility to cover state responsibility when the latter is not clearly and directly established.
\end{abstract}

The debate on these issues have been complicated by the fact that the United States government has taken a hostile view of the drive to establish a permanent international criminal law. It has further been complicated by the Bush administration's stated intention to try suspected terrorists by military tribunals that escape the strict principles of due process and natural justice generally applicable in the judiciary systems of Western democracies.

International law publicists have generally taken a dim view of the US government's hostility to the international community's drive to establish a permanent International Criminal Court. In discussing theses issues, I find that the opinions of international lawyers are generally divided on whether the war against Afghanistan was a war of self-defence by reference to customary law or by reference to the United Nations resolutions. I also find that those lawyers finding that the war

\footnotetext{
* Prof. Dr. Adel Safty is Professor of International Relations and Law, and Dean of Leadership and Public Affairs at Bahcesehir University. Istanbul.
} 
could be justified as a just war or a war of self-defence made tentative cases that required broad and liberal interpretations of the texts examined. Those finding that the war against Afghanistan was not a war of self-defence, nor a just war were more assertive and generally made stronger, if not unassailable cases.

On the basis of these findings, it is suggested that the better view is that the Bush administration has broadened the concept of self-defence, has created a new principle deeming states 'harbouring' terrorists to be themselves terrorists, thus creating state responsibility by extension from individual criminal responsibility. In the absence of challenges, these interpretations may become important precedents to be invoked in the future by the USA or by other states to justify similar actions. This may broaden the concept of security by self-help and reinforce the structure of the international relations system as an anarchical order, weakening the international community's efforts to bring order and stability to the system through multilateral institutions such as the UN and the International Criminal Court. In one sense, the war against Afghanistan may be the Bush administration's response to the international community's drive to establish the International Criminal Court.

\section{International Criminal Law}

Following World War II the victorious Allies established, in 1945, the Nuremberg and Tokyo Tribunals to prosecute individuals from the defeated Axis powers for criminal responsibility for crimes and atrocities associated with the war.

The Judgment of the Nuremberg Tribunal stated that "crimes against international law are committed by men, not by abstract entities, and only by punishing individuals who commit such crimes can the provisions of international law be enforced" The Tribunal thus established in international criminal law the principle of individual criminal accountability.

In addition, the Tribunal's jurisdiction covered three types of crimes for which there would be individual criminal responsibility. The Charter of the International Military Tribunal established jurisdiction over these three kinds of crimes:

(a) Crimes against Peace: namely, planning, preparation, initiation or waging of a war of aggression, or a war in violation of international treaties;

(b) War Crimes: including but not limited to such crimes as murder, illtreatment or deportation to slave labour or for any other purpose of civilian 
population of or in occupied territory, murder or ill-treatment of prisoners of war or persons on the seas, killing of hostages;

(c) Crimes against Humanity: namely, murder, extermination, enslavement, deportation, and other inhumane acts committed against any civilian population, before or during the war...

In affirming the Nuremberg Tribunal, the UN General Assembly voted in favour of codifying the principles recognized in its Charter and judgment.

In 1948, the United Nations adopted the Convention on the Prevention and Punishment of the Crime of Genocide, recognizing that the crime of genocide may be committed by constitutionally responsible rulers, public officials or private individuals.

In resolution 260 (December, 9 1948), the General Assembly, "recognizing that at all periods of history genocide has inflicted great losses on humanity; and being convinced that, in order to liberate mankind from such an odious scourge, international co-operation is required", adopted the Convention on the Prevention and Punishment of the Crime of Genocide. Article I of that convention defines genocide as "a crime under international law", and article VI provides that persons charged with genocide "shall be tried by a competent tribunal of the State in the territory of which the act was committed or by such international penal tribunal as may have jurisdiction . . "Resolution 260 also invited the International Law Commission "to study the desirability and possibility of establishing an international judicial organ for the trial of persons charged with genocide..."

With the support of the International Law Commission, the General Assembly established a committee, which proposed in 1951 a draft statute for a criminal court, followed by a revised statute in 1953. The court was never established because of the inability of the UN members to agree on an acceptable and universally applicable definition of aggression.

With the end of the Cold War and the collapse of the Soviet Union in the late 1980s, the General Assembly revived the possibility of establishing a permanent criminal court. The disintegration of the Republic of Yugoslavia in 1993 and the ethnic cleansing and war crimes that took place during that conflict gave urgency to the issue of bringing to justice the perpetrators of war crimes. The Security Council decided to establish the ad hoc 
International Criminal Tribunal for the Former Yugoslavia to try individuals accused of committing war crimes. At the same time the drive to establish a permanent international criminal court moved apace. Another draft statute was submitted to the General Assembly in 1994, and in 1995, the General Assembly created the Preparatory Committee on the Establishment of an International Criminal Court (ICC), which completed, in 1998, a consolidated draft text to be submitted to an international diplomatic conference. The conference was held in Rome, Italy, from 15 June to 17 July 1998, to "finalize and adopt a convention on the establishment of an international criminal court".

\section{The Rome Diplomatic Conference June 1998}

Delegations from 160 countries and dozens of NGOs were presented, on June 15, 1998 in Rome, with the task of agreeing, by July 17, on some 1400 clauses in the draft statute of the ICC on which there was no agreement. Most of these clauses (bracketed clauses) dealt with the important issues of jurisdiction of the ICC, the mechanism for triggering that jurisdiction, the issue of how to protect national security information requested by the ICC, and finally how the ICC would be financed. Although important, the question of financing should not concern us here and so we shall leave it aside.

The draft statute provided for jurisdiction over genocide, crimes against humanity, and serious violations of international humanitarian law. The ICC's jurisdiction for the crime of aggression is subject to a finding of aggression by the Security Council, and therefore the definitional problem of aggression is bypassed, since it is left to the Security Council to make a finding of aggression. Such a finding obviously will be subject to the veto power of the permanent members and therefore will necessarily be a reflection of political, not necessarily judicial or equitable considerations.

On the question of triggering mechanism, the draft statute provided for a compromise between those who would have liked to see a completely independent court with compulsory jurisdiction triggered by any state party to the convention or by the prosecutor of the court, and those who wanted the court to be subject to the political considerations of the Security Council. The draft provided therefore for both track of triggering mechanisms. The first track being the one where the Security Council will remain the ultimate body that will trigger the applicability of the Court's jurisdiction. The second track being the one triggered by anyone of the states party to the convention or by the ICC prosecutor. Under the principle of complementarity, the second track would be utilized only as a last resort where no country is willing and able to 
prosecute a particular case. The major debate at the Rome Conference was about how much power this second track would have. A small number of countries led by the USA essentially wanted a prosecutor with no authority to initiate investigations on his own. The majority of members present advocated the establishment of a fully independent prosecutor's office. The US insisted that the Security Council's authorisation should be required before any investigation could be initiated. This would have meant a veto power for the permanent members of the Security Council over which crimes and which individuals to prosecute. Although only the parties to the ICC statute would be bound to cooperate with the court under the second track, there is no mechanism for ensuring compliance. The parties to the ICC statute would be bound to cooperate with the Court under the second track, and there is no built-in means of ensuring compliance. No agreement was reached on the definition of aggression. The Statute simply provides that the Court may not exercise jurisdiction over the crime of aggression until agreement is reached by States Parties at a Review Conference on the definition and elements of aggression.

Criminal responsibility will apply equally to all persons without distinction whether the accused is a Head of State or a high government official. In other words, official capacity will not provide any immunity from persecution.

The Court's jurisdiction will not be retroactive. It can only address crimes committed after the entry into force of the Statute and the establishment of the court.

The Statute and the Final Act were put forward as a complete "package" for adoption by the delegates. The package was agreed in its entirety by a vote of 120 in favour, 7 against with 21 abstentions. The United States voted against because it objected to the power given to the second track jurisdiction and wanted the Security Council to be the determiner of acts of aggression. Israel voted against because it objected to the inclusion in the list of war crimes adopted by the statute of the act of transferring populations into occupied territories, which would make the establishment of Jewish settlements in the occupied Palestinian territories a war crime.

The $20^{\text {th }}$ century has seen the worst violence in the history of humankind. Since the establishment of the United Nations in 1945, there have been more than 250 conflicts that resulted in the death of more than 86 million civilians. However, the most serious violations of human rights have occurred, not in international conflicts, but within States. By incorporating into the statute of 
the ICC contemporary international humanitarian law standards that criminalize, as war crimes, serious violations committed in internal armed conflicts, the statute extends the reach of international law beyond the protective shield of national sovereignty and internal domestic matters. United Nations Secretary-General Kofi Annan hailed the agreement as "a giant step forward in the march towards universal human rights and the rule of law."

\section{US Objections}

Less than a week after the Rome Conference ended, the US Senate Subcommittee on International Operations, of the Committee on Foreign Relations met, on Thursday July 23, 1998, to examine the following question: Is A U.N. International Criminal Court In The U.S. National Interest?

In his opening remarks, Senator Grams, chairman of the Subcommittee, had this to say:

The fact remains, the most effective deterrent is the threat of military action; and this court is undermining the ability of the United States to do that very thing...the International Criminal Court is a monster. First, the ICC will have the final determination over whether it has jurisdiction over the case. Under a system of complementarity, the ICC can override the decision of a nation's judicial system and it can pursue a case if it decides that a State is unwilling or unable to do so. In other words, if an ICC prosecutor wanted to investigate and charge the President of the United States for a bombing raid like the one President Reagan conducted in Libya, our only way to prevent the case from going forward would be to have our own Justice Department investigate the President. If the U.S. Government then declined to prosecute, it would still be up to the judgment of the ICC whether to prosecute and pursue the case.

A decision by the International Criminal Court to prosecute Americans for military action would not be the first time that an international court tried to undercut our pursuit of our national security interests. In 1984, the World Court ordered the U.S. to respect Nicaragua's borders and to halt the mining of its harbours by the CIA. In 1986, the World Court found our country guilty of violations of international law through its support of the Contras and ordered the payment of reparation to Nicaragua. Needless to say, we ignored both of those rulings. ${ }^{1}$ 
Senator Helms, the Chairman of the Committee on Foreign Relations, was equally forceful in his opposition to the International Criminal Court:

It will be a crime of aggression when the United States of America takes any military action to defend the national interest of the American people unless the United States first seeks and receives the permission of the United Nations. And I say baloney to that. Just imagine what would have happened if this court had been in place during the U.S. invasion of Panama or the U.S. invasion of Grenada or the United States bombing of Tripoli. In none of those cases, did the United States seek permission from the United Nations to defend our interest. The United States will not provide any assistance whatsoever to the Court or to any other international organization in support of the Court either in funding or in-kind contributions or other legal assistance. The United States shall not extradite any individual to the Court or directly or indirectly refer a case to the Court. The United States shall include in all of its bilateral extradition treaties a provision that prohibits a treaty partner from extraditing U.S. citizens to this court. The United States shall renegotiate all of its status of forces agreements to include a provision that prohibits a treaty partner from extraditing U.S. soldiers to this court and will not station American forces in any country that refuses to accept such a prohibition. The United States shall not permit a U.S. soldier to participate in any NATO, United Nations, or other international peacekeeping mission until the United States has reached agreement with all of our NATO allies and the United Nations that no United States soldier will be subject to the jurisdiction of this court. ${ }^{2}$

In his last few days in office, however, President Clinton, who had opposed the treaty, changed his mind and signed the treaty arguing that the US would have a better chance of influencing the final outcome if it were a signatory. It is, however, highly unlikely that the treaty will receive the required two third majority in the Senate for ratification, given the strength of opposition to its underlying principles. On September 10, 2001, the Senate passed an amendment to the Commerce, Justice, State and Judiciary Appropriations Bill, which bars any further US participation in negotiations about the court and obstructs government cooperation with it. Earlier legislation forbids any American financial contribution for settling up the International Criminal Court.

The dilemma for the Bush administration is that President Clinton committed the United States by signing the Rome treaty, while both at the White House of the Bush administration and in Congress, there is little support for the treaty. And as might be gathered from the Senate hearings 
there are active attempts at aggressively opposing the treaty. Now, Article 18 of the Vienna Convention on the Law of Treaties (1969) provide that states that signed a treaty but not yet ratified it are required not to defeat the purpose of the treaty unless they explicitly renounce the treaty. Such a scenario, i.e.; the renunciation of the treaty, is not inconceivable given the precedent of the Kyoto treaty on environmental protection signed by the USA and repudiated by the Bush administration.

\section{Universal Jurisdiction}

Even though the International Criminal Court is not yet established, terrorist acts deemed crimes against humanity may be subject to prosecution in domestic criminal courts anywhere in the world. Under customary international law, the United States would have jurisdiction to proscribe terrorist acts that take place in the United States, and institute criminal proceedings against the offenders on the basis of existing anti-terrorist laws.

Other countries could exercise what is known as universal jurisdiction. Universal jurisdiction means criminal jurisdiction based only on the nature of the crime, without regard to where the crime was committed, the nationality of the alleged or convicted perpetrator, the nationality of the victim, or any other connection to the state exercising such jurisdiction. Any competent judicial body of any state may invoke the principle of universal jurisdiction to try a person duly accused of committing serious crimes under international law, provided the person is present before such judicial body. These crimes include: piracy; slavery; war crimes; crimes against peace; crimes against humanity; genocide; and torture. Any state may rely on universal jurisdiction as a basis for seeking the extradition of a person accused or convicted of committing any of these crimes provided that it has established a prima facie case of the person's guilt. The person sought to be extradited must also be tried, and if convicted punished, in accordance with established norms of protection of human rights in criminal proceedings. In exercising universal jurisdiction or in relying upon universal jurisdiction as a basis for seeking extradition, a state and its judicial organs must observe international due process norms including those involving the rights of the accused and victims, the fairness of the proceedings, and the independence and impartiality of the judiciary. 
But the option of a public trial grounded in anti-terrorism domestic laws of the USA is unlikely given the Bush administration's commitment to using military tribunals if and when the presumed perpetrators of terrorist attacks against the USA are captured and brought before justice. The option of universal jurisdiction remains valid for those countries willing to commit themselves to a public trial of presumed perpetrators of terrorist acts on the basis of international due process, that is taking account of the principles of universal jurisdiction for the protection of human rights within the context of criminal proceedings.

\section{September 11 and its Aftermath}

On September 11, three civilian planes were hijacked and made to crash against the twin towers of the World Trade Centre in New York, and against the Pentagon in Washington DC, (a fourth hijacked airliner crashed in Pennsylvania), resulting in the death of thousands of civilians. The suspected terrorists were reportedly from Middle Eastern origins. The Bush administration accused Mr. Ossama BinLaden, a suspected terrorist who reportedly was involved in previous attacks against American embassies in Africa. The Bush administration also said that it considered these attacks an act of war. The Secretary General of NATO reinforced this position by invoking, for the first time, article 5 of the organisation's charter which provides for members of NATO to come to the defence of any other member of NATO if that member country came under armed attack.

Mr. Bush said he wanted Mr. Bin Laden "dead or alive," although U.S. Secretary of Defence Donald Rumsfeld later said that he preferred to have him dead, suggesting that to have him alive would cause all sorts of complications. The Bush administration also made it clear that they would hold those who "harbour" terrorists also responsible, in this case the Taliban regime in Afghanistan. The Bush administration and the Blair government in Britain demanded that the Taliban regime hand over Mr. Bin Laden and close down the training camps of Al Qua'ada in Afghanistan, or else face the consequences. When the Taliban regime failed to hand over Mr. Ossam Bin Laden and close down the Al Qua'ada training camps, the United States and Britain with the support of other Western allies, launched, on October 7, a war against Afghanistan. 
The Nuremberg Tribunal defined crimes against humanity as "murder...and other inhumane acts committed against civilian population." The Statute of the International Criminal Court expanded on the definition of crimes against humanity to include any of several listed acts "when committed as part of a widespread or systematic attack directed against any civilian population, with knowledge of the attack." The acts include murder and "other inhumane acts of a similar character intentionally causing great suffering, or serious injury to body or to mental or physical health."

The September 11 attacks were obviously planned and executed with intent to kill, and resulted in the killing of civilians. They would therefore qualify as crimes against humanity in international law.

Assuming there is admissible evidence against Mr. Bin Laden to indict him as a war criminal with individual responsibility for the events of September 11, his individual criminal responsibility will be established. The same cannot be said for the question of state responsibility of the state of Afghanistan. The Bush administration did not suggest that the Taliban regime had a direct responsibility in ordering the September 11 attacks, and the Taliban regime denied that Afghanistan had anything to do with it.

The Bush administration stated that it was holding the state of Afghanistan responsible for 'harbouring' terrorists. But it is doubtful that this can give rise to state responsibility for an act of war against the United States. The presumed perpetrators of these events were not nationals in the service of the state of Afghanistan and do not appear to have been acting under order from the State of Afghanistan. Moreover, Mr. Bin Laden and his associates appear to have denied any responsibility, as did the government of Afghanistan, for these acts.

As Prof John Cerone, Executive Director of the War Crimes Research Office at American University Washington College of Law, pointed out: "While it is well established that an international obligation may be breached through an act or an omission, mere inaction would likely be insufficient to give rise to state responsibility for the acts in this case. According to the Draft Articles on State Responsibility, "The conduct of a person or group of persons shall be considered an act of a State under international law if the person or group of persons is in fact acting on the instructions of, or under the direction or control of, that State in carrying out the conduct.", 
There is an important precedent confirming this established position. In 1985 , Israel tried to establish state responsibility not on the basis of direct control or instruction from state to perpetrators but on the basis of mere presence of presumed perpetrators on the territories of the said state. Israel tried to justify its attack on the Palestine Liberation Organisation's headquarters near Tunis, in Tunisia, on October 1, 1985, by claiming that the state 'harbouring' perpetrators should be deemed themselves to be perpetrators. The then Israeli representative at the UN, Benyamin Netanyahu told the UN Security Council: "A country cannot claim the protection of sovereignty when it knowingly offers a piece of its territory for terrorist activity against other nations, and that is precisely what happened here. Tunisia knew very well what was going on in this extraterritorial base, the planning that took place there, the missions that were launched from it, and the purposes of those missions: repeated armed attacks against my country and against innocent civilians around the world. Tunisia, then, actually provided a base for murderous activity against another State and, in fact, the nationals of many States who are the objects and victims of this terrorist organization."

The UN Security Council rejected that argument and voted, 14 to zero, with the United States abstaining, to condemn the Israeli action. Resolution 573 condemned "vigorously the act of armed aggression perpetrated by Israel against Tunisian territory in flagrant violation of the Charter of the United Nations, international law and norms of conduct." It described the air raid as a "threat to peace and security in the Mediterranean region." The resolution requested UN member states "to take measures to dissuade Israel from resorting to such acts against the sovereignty and territorial integrity of all States." The resolution further declared that Tunisia was entitled to appropriate reparations for loss of human life and material damage.

\section{Is the War against Afghanistan a war of self-defence?}

The Bush Doctrine claims that the state of Afghanistan is responsible for acts of war or acts that amount to war against the United States and that the United States acted in self-defence in waging war against Afghanistan. President Bush repeatedly declared that states 'harbouring' terrorists are to be deemed themselves terrorists, and shall be "held accountable." If we put aside the vexing issue of who and how to hold such states accountable, and we accept, for argument's sake, that Afghanistan may be held responsible through the Bush Doctrine of extension of criminal responsibility, there 
remains the question of how to justify the war against Afghanistan. The Bush administration said it was a war of self-defence. This presumably disposes of the peaceful alternative of taking Afghanistan to the International Court of Justice, a judiciary process which is not politically popular under the circumstances, and under which the indictment of Afghanistan is far from certain, because among other reasons of the difficulty inherent in establishing state responsibility for the events of September 11. This leaves the question of the nature of the war against Afghanistan. Is it a war of self-defence?

The universally accepted classic formulation for self-defence was set out in the Caroline case. The Caroline doctrine set out the conditions under which force can legitimately be used in self-defence under customary international law, which was subsequently confirmed and employed in the Nuremberg Tribunal.

In 1837, The British navy, while in United States territory, sank the American steamship, Caroline. The British claimed that their use of force in U. S. territory was justified because it was done in self-defence after the Caroline had been used in American raids into Canadian territories. The United States rejected that claim and US Secretary of State Daniel Webster wrote to the British government, and the British government eventually accepted, the classic formulation that came to be widely accepted as customary law of self-defence: "'There must be a necessity of self-defence, instant, overwhelming, leaving no choice of means, and no moment for deliberation. [The means of self-defence must involve] nothing unreasonable or excessive; since the act, justified by the necessity of self-defence, must be limited by that necessity, and kept clearly within it."

This formulation of self-defence was accepted and used by the Nuremberg Tribunal whose Charter was used by the United Nations as a basis for codifying its various provisions. The Geneva Protocol of 1977 reflected the codification of the principles laid down in the Nuremberg Tribunal's Charter and customary law on self-defence as outlined above. The United States signed but did not ratify the Geneva Protocol.

Thus, the doctrine of self-defence is based on "a necessity of selfdefence, instant, overwhelming, leaving no choice of means, and no moment for deliberation." Since the September 11 attack began and ended within a matter of minutes, the "instant, overwhelming," necessity of self-defence arose and ended within a matter of minutes. The war against Afghanistan started about a month after the September 11 attack. It clearly was not designed to prevent an "instant, overwhelming" danger that left "no choice of 
means, and no moment for deliberation" That is because the high jacked planes did not come from Afghanistan and there was no evidence to suggest that attacks similar to those of September 11 were about to be launched from Afghanistan. The war against Afghanistan thus may serve as an eventual deterrent of future terrorist attacks, though this is far from certain; it may serve as punishment, though not necessarily of the actual perpetrators, but it cannot be said to be a self-defence measure designed to stop an instant and overwhelming danger. The war against Afghanistan, if it is to be viewed as self-defence as opposed to an act of vengeful retaliation and deterrence, must find legal justification elsewhere, either in the Charter of the United Nations, by special reference to the doctrine of just war, or, ultimately by reference to new and developing principles in customary law.

Some international law publicists seem to think that a case could be made to defend the war as an act of self-defence, either by reference to the Charter of the United Nations, or, as Professor Richard Falk argued, by reference to the just war doctrine.

Article 2 (4) of the UN Charter positively forbids the use of force. It orders that, "All Members shall refrain in their international relations from the threat or use of force." Article 51 spells the conditions under which self-defence may become an exception to this rule:

"Nothing in the present Charter shall impair the inherent right of individual or collective self-defence if an armed attack occurs against a Member of the United Nations, until the Security Council has taken measures necessary to maintain international peace and security. Measures taken by members in the exercise of this right of self-defence shall be immediately reported to the Security Council and shall not in any way affect the authority and responsibility of the Security Council under the present Charter to take at any time such action as it deems necessary in order to maintain or restore international peace and security."

With this in mind, Professor Frederic Kirgis argues that Security Resolution 1373 reaffirms that terrorist acts constitute a threat to international peace and security, and reaffirms the inherent right of individual or collective self-defence as recognized by the Charter. He recognizes that although this is not a Security Council approval of the use of armed force in self-defence as a response to the events of September 11, "it may be taken as an indication of the Security Council's recognition that the right of selfdefence could arise from those events." Further he writes that the expression 
in the resolution of the Security Council is determined "to take all necessary steps" to ensure full implementation, is reminiscent of "the Council's authorization to member states in Resolution 678 to "use all necessary means" to restore international peace and security after Iraq invaded Kuwait in 1990". Professor Kirgis recognizes, however, that Resolution 1373 does not authorize states to take all necessary steps to implement it. ${ }^{5}$

Professor Jordan Paust of the University of Houston, however, expresses no reservations. He argues that "the targeting of non-state or state leaders and entities in charge of or directly engaged in the attack is a permissible measure of self-defence under Article 51 of the United Nations Charter, a treaty of the United Sates. A self-defence military mission to capture and arrest those ordering and directly engaged in ongoing processes of attack would also be permissible under the Charter" In another article, he argues that war is justified as a self-defence: "I do not believe," he writes, "that use of the phrase "all necessary means" is absolutely required in order for the Security Council to authorize the use of armed force. The Council can use any words it prefers to authorize military and other action, although it is correct that the phrase appears in a far earlier authorization of armed force with respect to Iraq in Resolution 678 (29 Nov. 1990) and in Resolution 816 (31 Mar. 1993) regarding the authorization to use military force in Bosnia-Herzegovina." $\mathrm{He}$ believes that the statement in the preamble of the resolution reaffirming "the need to combat by all means, in accordance with the Charter," terrorist threats to international peace and security is close enough to the classic formulation of "all necessary means." Especially with regard to paragraph 3 (c) of the resolution, which, "Calls upon all States to... cooperate, particularly through bilateral and multilateral arrangements and agreements, to prevent and suppress terrorist attacks and take action against perpetrators of such acts."

Professor Said Mahmoudi of the University of Stockholm seems to support this interpretation. In Security Council resolution 1368 (2001), he writes, the members of the Security Council unanimously recognized the right of each State to individual and collective self-defence in situations like the present one in the US. "The Security Council seems to equate terrorist acts, or at least those that claim a great number of civilian victims, with armed attacks in the sense of Article 51 of the UN Charter Reference to the recent catastrophe as "a threat to international peace" and talking of "all necessary steps to respond to the terrorist attacks of 11 September 2001"' he concludes, "reinforce this impression." 
But it is the Security Council itself, not member states, which in Resolution 1368, was "determined to combat by all means threats to international peace and security caused by terrorist acts." And it is the Security Council that stood ready "to take all necessary steps to respond to the terrorist attacks of 11 September 2001, and to combat all forms of terrorism, in accordance with its responsibilities under the Charter of the United Nations."

The Security Council signalled that it remained in charge of peace and security and did not authorize anyone to use force on its behalf. For instance, Resolution 1373 enumerated an array of means to combat terrorism. It ordered member states to freeze terrorist assets, criminalize the financing and support of terrorist, exchange police information about terrorists, prevent movement of terrorists through increased border controls, and capture and prosecute terrorists. It did not mention the use of force.

This is also the conclusion reached by a number of other critical views. For instance, Professor Michael Mandel, from Osgood Hall Law School in Toronto, argued that regardless of what others said, this war against Afghanistan was illegal because it violated international law and the express words of the Charter of the UN. He argues that the right to self-defence under Article 51 does not apply in this case because article 51 gives the right to self-defence to repel an attack that is ongoing or imminent as a temporary measure until the UN Security Council can take the necessary steps for restoring international peace and security.

The two resolutions of the Security Council condemning the Sept. 11 attacks could not, in his view, be "remotely" said to authorize the use of military force. Professor Mandel goes on to conclude: "The right of selfdefence in international law is like the right of self-defence in our own law: It allows you to defend yourself when the law is not around, but it does not allow you to take the law into your own hands. Since the United States and Britain have undertaken this attack without the explicit authorization of the Security Council, those who die from it will be victims of a crime against humanity, just like the victims of the Sept. 11 attacks."

\section{By reference to the doctrine of Just War}

The classic formulation of self-defence referred to above is based on various military and ethical doctrines, principally the Just War Doctrine, developed by St. Augustine of Hippo with important subsequent 
contributions by St. Thomas Aquinas and Gratium, and, in the $20^{\text {th }}$ century, by Paul Ramsey and others.

This doctrine provides that: (a) the just war must be one of necessity; that is as a last resort, when all other avenues have been exhausted; (b) there must be a just cause for war; (c) that such a just war must have a reasonable chance of success; (d) that self-defence is a just cause, but that the just war in self-defence must be based on, (e) the principle of discrimination (to discriminate between military and civilian targets); and (f) the principle of proportionality (the responsive measure must be proportionate to the original attack). St. Augustine specifically ruled out as justifiable causes for war the desire for revenge or the impulse for dominating.

In the October 29 issue of the Nation, Richard Falk, a leading scholar of peace and justice studies in the USA, argued that the war in Afghanistan was a just war. "The war in Afghanistan against apocalyptic terrorism," he wrote, "qualifies in my understanding as the first truly just war since World War II." 10

Falk identifies the most important principles of just war that he considered in his case for the war as follows:

1. The principle of discrimination: force must be directed at a military target, with damage to civilians and civilian society being incidental;

2. The principle of proportionality: force must not be greater than that needed to achieve an acceptable military result and must not be greater than the provoking cause;

3. The principle of humanity: force must not be directed even against enemy personnel if they are subject to capture, wounded or under control (as with prisoners of war);

4. The principle of necessity: force should be used only if non-violent means to achieve military goals are unavailable.

Falk, who long opposed US military interventions abroad and who wrote in the same article that the global role of the United States "is certainly responsible for much global suffering and injustice," was roundly criticized by the anti-war camp. 
Falk himself recognized the limitations of the first principle, that of discrimination. He wrote: "the justice of the cause and of the limited ends is in danger of being negated by the injustice of improper means and excessive ends."

As for the other three principles, there is evidence to suggest that it would be at best problematic to make a persuasive case that these principles applied to the war against Afghanistan. First, the principle of proportionality. Professor B. Welling Hall pointed out an obvious dilemma: "The terrorist attacks on the World Trade Centre (if not the Pentagon) on September 11, 2001 pose the legal dilemma of how to respond proportionally when the initial attack was itself unreasonable, excessive, and against civilians. Nonetheless, the suggested policy of holding entire nations accountable for the acts of a few would not appear to be lawful since collective punishment would, by definition, entail the unnecessary suffering of innocent populations." "11

This leads to the second principle, that of humanity. The impact on the civilian population was reasonably well predictable before the war started. The New York Times reported a few days before the war that "the threat of American-led military attacks turns" the Afghan people's "long-running misery into a potential catastrophe." ${ }^{\text {12 }}$ United Nations and other relief agencies have been warning about a great humanitarian crisis that would become even worse in the event of a war. The Bush administration therefore knew or ought to have known that given the humanitarian crisis of Afghanistan a war was likely to make it worse and therefore make it virtually impossible to respect the just war principle of discrimination, to discriminate between military and civilian targets so as not to harm the civilians in any way. On November 13, as the Northern Alliance reached Kabul, Amnesty International received reports of summary execution of the captured fighters. It warned that "the civilian population of Afghanistan has again been put at risk by the failure of the international community to protect them.."13

Finally, the principle of necessity, namely that the war must be a last resort after all else, especially negotiations, have failed, is easily dealt with, because the Bush administration refused to enter into any negotiations with the Taliban regime in the first place. On October 5 the Taliban ambassador to Pakistan offered a negotiated settlement to the crisis and stated that his country was ready to try Osama Bil Laden: "We are prepared to try him if America provides solid evidence of Osama bin Laden's involvement in the attacks on New York and Washington." Asked if bin Laden could be tried in 
another country, the ambassador said, "We are willing to talk about that, but ... we must be given the evidence." Indeed, said the ambassador, legal proceedings could begin even before the United States offered any evidence: "Under Islamic law, we can put him on trial according to allegations raised against him and then the evidence would be provided to the court." Washington dismissed the ambassador's remarks, refused to provide evidence saying its demands were non-negotiable. ${ }^{14}$

Michael Ratner and Jules Lobel, respectively from Human Rights Now and the University of Pittsburgh Law School, argued that there was another way to respond to the terrorist attack of September 11: "Treat the attacks on September 11 as a crime against humanity (mass or systematic killing of civilians), establish a U.N tribunal, extradite the suspects, or if that fails, capture them with a U.N. force, and try them. The U.S. experience with Libya demonstrates both the perils of a military response and the possibilities for international justice. Initially, the U.S. bombed Libya for its alleged role in the killing of U.S. soldiers; Libya retaliated by bombing Pam Am 103 over Lockerbie. At that point, U.S. officials recognized that more bombing would lead to a spiralling cycle of violence and turned to the U.N. International pressure was applied; and eventually the Libyans extradited the suspects for trial." 15

They criticized Falk's objections to this alternative: "The numerous objections Falk makes to such a tribunal primarily revolve around his belief that the U.S. would not accept such a court, in part, because it might not be authorized to give the death penalty. But since when should respected international legal experts like Falk, who generally favour peaceful resolutions to conflicts, shy away from arguing what is right simply because they believe the U.S. will not listen." 16

Howard Zinn, a distinguished writer for the Progressive, argued that the progressive supporters of the war have confused a "just cause" with a "just war." "There are unjust causes," he wrote, Panama or Grenada, or to subvert the government of Nicaragua. And a cause may be just--getting North Korea to withdraw from South Korea, getting Saddam Hussein to withdraw from Kuwait, or ending terrorism--but it does not follow that going to war on behalf of that cause, with the inevitable mayhem that follows, is just."17

But, it was Stephen Shalom who mounted the strongest criticisms of Falk's arguments. Falk dismissed the option of a public trial of Ossama bin 
Laden on the following terms: "the evidence linking bin Laden to the September 11 attacks and other instances of global terrorism may well be insufficient to produce an assured conviction in an impartial legal tribunal, particularly if conspiracy was not among the criminal offences that could be charged. European and other foreign governments are unlikely to be willing to treat conspiracy as a capital crime." Shalom ridiculed that argument: "We should reject a trial because the evidence may not be sufficient to convict? But yet the evidence is good enough to wage war, with all its horrendous consequences? And then there's that capital punishment argument again: the evidence may be sufficient only if conspiracy can be charged -- which of course it can be -- but this may preclude execution. So instead we follow a course that will knowingly lead to a huge number of deaths."

Falk's second objection to the public trial option was that: "it also seems highly improbable that the US government can be persuaded to rely on the collective security mechanisms of the UN....". To which Shalom derisively responded: "It was also highly improbably that $\mathrm{Al}$ Capone could have been persuaded to rely on legal methods of earning a living. That doesn't make his criminal activities "truly just." ${ }^{19}$

\section{As part of a newly developing customary international law}

Customary international law is developed in a number of ways. One prominent way is through a process of assertion and acquiescence. Governments assert that they have a right to do something or that another government has no right to do what it is doing or proposes to do. If the other interested governments acquiesce in the assertion, a precedent is set. Such a precedent is not necessarily authoritative, and is subject to interpretation or even rejection. Like all precedents in domestic as well as international law, it is limited by its particular facts. If a comparable fact situation later arises, government officials may apply the precedent by analogy or may attempt to distinguish it from their situation. This will have the effect of confirming, expanding or limiting the precedent.

The International Court of Justice (ICJ)'s decisions show that a State, which relies on an alleged international custom practised by States must, generally speaking, demonstrate to the Court's satisfaction that this custom has become so established as to be legally binding on the other party. In the North Sea Continental Shelf cases the ICJ stated, with respect to customary international law: "Not only must the acts concerned amount to a settled practice, but they must also be such, or be carried out in such a way, as to be 
evidence of a belief that this practice is rendered obligatory by the existence of a rule of law requiring it." ${ }^{20}$

Similarly, in the case of the Continental Shelf (Libyan Arab Jamahiriya/Malta) it recalled that "the material of customary international law is to be looked for primarily in the actual practice and opinio juris of States". ${ }^{21}$

It also stated, in the case concerning Military and Paramilitary Activities in and against Nicaragua, where it found, owing to a reservation accompanying a declaration, that it could not deal with complaints based on certain multilateral treaties, that the reservation in question did not prevent it from applying the principles of customary international law. The fact that these principles "have been codified or embodied in multilateral conventions does not mean they cease to exist and to apply as principles of customary law, even as regards countries that are parties to such conventions". ${ }^{22}$

Such principles "continue to be binding as part of customary international law, despite the operation of provisions of conventional law in which they have been incorporated".

Critics argue that customary international law is subjective and inconsistent. States vary greatly in their opinions and interpretations of issues regarding international law. That is why the response of the Bush administration to the September 11 events is likely to represent over time part of an evolving international law custom that has expanded the definition of self-defence and introduced a novel way of asserting state criminal responsibility by extension from individual criminal responsibility. Although it has not been seriously challenged, this does not mean that it will not in the future, especially if such a precedent is relied upon by a lesser power than the United States.

\section{Conclusion}

The issue of dealing with the attacks against the World Trade Centre, if not the Pentagon, as crimes against humanity and bringing the offenders to public trial as war criminals may still arise, though it is now complicated by the commitment of the Bush administration to use military tribunals to try suspected terrorists. 
The issue of the war against Afghanistan as self-defence is debatable. At worst, the interpretation of self-defence is rejected either by reference to customary international law or by reference to the UN resolutions regarding the events of September 11 and by reference to the UN Charter. At best, the assertion of self-defence is arguable only through a liberal and broad interpretation of the texts of the UN resolutions. On December 20, Secretary of Defence Donald Rumsfeld said the US did not need other UN authorisations to take its war on terrorism to other countries, presumably suggesting that the Bush Doctrine applied to Afghanistan could be applied to other countries to justify possible US military actions against other countries. $^{23}$

The issue of the war as a Just War is dependent on the previous issue. If it were a war of self-defence, this will reinforce the case of a Just War, if it could be shown that the principles of necessity, discrimination, proportionality and humanity have been more or less respected.

The most significant issue to be raised by the events of September 11 and the response of the USA has to do with what might be called the Bush Doctrine: states 'harbouring' terrorists are deemed themselves to be terrorists. This extends individual criminal responsibility to create state criminal responsibility where none was evident. The Bush administration tried to use the same doctrine to accuse Iraq of criminal responsibility for the death caused by the anthrax letters mailed in the USA. The New York Times, reported that the Bush administration continued to try to establish a link between Iraq and the anthrax letters even after scientific evidence failed to establish such a link. ${ }^{24}$

President Bush also sought to extend his doctrine to create state criminal responsibility from the mere fact of developing nuclear weapons. On November 26, President Bush fielded questions from reporters at a White House reception for the two American aid workers who had been freed and flown home from Afghanistan, via Pakistan. In a reply to a question about which country was next on the list of countries harbouring terrorists and therefore to be held accountable according to the new Bush Doctrine, President Bush seems to have expanded his definition of terrorism to include countries that have developed or are developing weapons of mass destruction "with which to terrorise the world", he said. He singled out Iraq and North Korea. This attempt to construe the development of nuclear weapons as an act of terrorism will most likely not find support in any doctrine of self- 
defence. Should Iraq or North Korea refuse to let inspectors verify that they are not developing weapons of mass destruction, as President Bush seemed to demand of them, it would be most unlikely if the international community accepted to go along with the extension of the Bush Doctrine to view these states as having committed an act of terrorism against the United States or the international community calling for unilateral measures of self-defence.

Even without the extension of the Bush Doctrine, the acquiescence of the international community in the Bush Doctrine suggests that the doctrine may have established new precedents, which, if unchallenged, can eventually become part of customary law providing justification for similar rationalisations of military responses to acts of terrorism. Although a military component may be necessary to the international community's response to terrorism, the acceptance of the Bush Doctrine of extension of individual criminal responsibility to state criminal responsibility and the individual state right to wage war against such states deemed to be terrorists strengthen the self-help doctrine at the expense of international criminal law. As such, it may not necessarily contribute to the creation of an international environment of peace and security.

\section{Endnotes}

The US Committee On Foreign Relations, the Subcommittee on International Operations. Hearings. July 23, 1998.

${ }^{2}$ Ibid.

${ }^{3}$ John Cerone. Acts of War and State Responsibility in "Muddy Waters: The Non-State Dilemma." American Association of International Law Insights. September 2001.

${ }^{4}$ UN Doc. S/PV.2615, at 86-7 (Oct. 4, 1985). Statement of Mr. Netanyahu.

${ }^{5}$ Frederic L. Kirgis. Security Council Adopts Resolution on Combating International Terrorism. American Association of International Law Insights. October 1, 2001. 
${ }^{6}$ Jordan Paust. War and Responses to Terrorism. American Association of International Law Insights. September, 2001.

${ }^{7}$ Jordan Paust. Security Council Authorisation to Combat Terrorism in Afghanistan. American Association of International Law Insights. October 23, 2001.

${ }^{8}$ Said Mahmoudi. Comments on Fox Addendum. American Association of International Law Insights. September 24, 2001.

${ }^{9}$ Michael Mandel. Say What You Want But This War Is Illegal. Globe and Mail. Toronto. October 9, 2001.

${ }^{10}$ Richard Falk. Defining a Just War. The Nation. October 29, 2001.

${ }^{11}$ B. Welling Hall. Addendum Related to Self-Defence. American Society of International Law Insights. September 2001.

${ }^{12}$ The New York Times. September 30, 2001.

${ }^{13}$ Statement by Amnesty International. November 13, 2001.

${ }^{14}$ See Justin Podur. No Negotiations? Znet. October 30, 2001.

${ }^{15}$ Michale Ratner and Jules Lobel. Creating the Terrorists that Will Visit Terror Upon Our Children. Znet. October, 2001. See also. Michael Ratner. An Alternative to the USA Employment of Force. Centre for Constitutional Rights. New York Center for Constitutional Rights.

${ }^{16}$ Ibid.

${ }^{17}$ Howard Zinn. A Just Cause, Not a Just War. The Progressive. October, 2001.

${ }^{18}$ Stephen R. Shalom. "A Just War?" A Critique of Richard Falk. Znet. October 21, 2001.

${ }^{19}$ Ibid. 
${ }^{20}$ Judgments, Advisory Opinions and Orders of the International Court of Justice: 1948-1991. The United Nations. New York, 1995.

${ }^{21}$ Ibid.

${ }^{22}$ Ibid.

${ }^{23}$ CNN. December 20, 2001.

${ }^{24}$ The New York Times. December 22, 2001.

\section{Bibliography}

Adel Safty. From Camp David to the Gulf. Black Rose: Montreal and New York, 1992, 1997

Adel Safty, editor. Leadership and the United Nations. The United Nations University. EMU Press: Northern Cyprus. 2000.

Adel Safty, editor. Notes, Cases, and Materials on International Law. EMU Press: Northern Cyprus. 2000.

Briely J, L. The Law of Nations, $6^{\text {th }}$ edition edited by Sir. H. Waldock, UK, 1961

Draft Code of Crimes against the Peace and Security of Mankind. www.un.org/law/ilc/texts/dcodefra.htm.

Judgments, Advisory Opinions and Orders of the International Court of Justice: 1948-1991. The United Nations. New York. New York. 1995

M. Cherif Bassiouni. A Casebook on Intermational Criminal Law, co-ed. Carolina Academic Press 1998, 2d rev, ed. 2000.

M. Cherif Bassiouni. International Criminal Law: Crimes, ed. Transnational Pub., Inc. 1986, 2d rev. ed. 1999. 
M. Cherif. Bassiouni. Statute of the International Criminal Court: A Documentary History, ed., Transnational Pub. 1998.

Rome Statute of the International Criminal Court. Published by the United Nations Department of Public Information. DPI/2016--October 1998.

The US Committee On Foreign Relations, the Subcommittee on International Operations. Hearings. July 23, 1998.

United Nations Diplomatic Conference of Plenipotentiaries on the Establishment of an International Criminal Court www.un.org/icc 